\title{
THE EFFECT OF PESTICIDES COUNSELING ON KNOWLEDGE AND PERSONAL HYGIENE AMONG RICE FARMERS IN SUKOHARJO, CENTRAL JAVA
}

\author{
Isna Qadrijati, Yuliana, Lusi Ismayenti \\ Diploma Program in Occupational Health and Safety, \\ Faculty of Medicine, Sebelas Maret University
}

\begin{abstract}
BACKGROUND: Rice is an important cash crop. Pesticides were commonly used to increase the crop yield in Sukoharjo, Central Java. However, their health impact has not been studied yet. Counseling on pesticide may boost farmers' understanding on the danger of pesticide. This study aimed to determine the effect of pesticide counseling on knowledge of pesticide safety and personal hygiene among rice farmers in Sukoharjo, Central Java.

SUBJECT AND METHODS: This was a quasi-experimental study, before and after with no control design. It was conducted in Nguter, Sukoharjo, Central Java. A sample of 60 rice farmers was selected for this study. The dependent variables were knowledge on pesticide and personal hygiene. The independent variable was counseling on pesticide. A questionnaire was developed to measure knowledge and personal hygiene. The difference in knowledge and personal hygiene scores before and after counseling was tested by Wilcoxon test.

RESULTS: Rice farmers had mild to moderate pesticide poisoning. This was because most farmers did not use any personal protective equipment during pesticide handling. Only a few used shoes (55\%), masks (15\%) and gloves (12\%) during pesticide spray. Mean knowledge on the effect of pesticide increased from 47.16 before intervention to 82.08 , and it was statistically significant $(\mathrm{p}<0.001)$. Mean personal hygiene on the effect of pesticide increased from 70.91 before intervention to 86 , and it was statistically significant ( $\mathrm{p}<0.001)$.

CONCLUSION: Rice farmers in Sukoharjo, Central Java, have mild to moderate pesticide poisoning, which is due to the lack of knowledge and personal hygiene. Most farmers do not use any personal protective equipment during pesticide handling.
\end{abstract}

Keywords: counseling, pesticide, knowledge, personal hygiene, rice farmer, protective equipment. 